\title{
Correlation Between Sphenoclivus Angle and Gnathic Angle with Age and Gender in Iranian Population using CT-Scan
}

\author{
Gholamreza Hassanzadeh 1,2, Ghazaleh Moshkdanian³, Morteza Gholaminejhad², \\ Mahnaz Poorhassan ${ }^{4}$, Babak Ebrahimi², Reza Habibi ${ }^{5}$, Parichehr Pasbakhsh², \\ Tayebeh Rastegar ${ }^{2}$, Mahdad Abdi ${ }^{2}$, Yasmin Yazdooei ${ }^{6}$, Masoumeh Gity ${ }^{7 *}$
}

\author{
Department of Neuroscience and Addiction Studies, School of Advanced Technologies in medicine, Tehran University of Medical Sciences, Tehran, Iran. \\ Department of Anatomy, School of Medicine, Tehran University of Medical Sciences, Tehran, Iran. \\ ${ }^{3}$ Institute for Basic Sciences, Kashan University of Medical Sciences, Kashan, Iran. \\ ${ }^{4}$ Department of Anatomy, School of Medicine, Shahid beheshti University of Medical Sciences, Tehran, Iran. \\ school of Medicine, Tehran University of Medical Sciences, Tehran, Iran. \\ Student Research Committee, Golestan University of Medical Sciences, Gorgan, Iran. \\ `Department of Radiology, Advanced Diagnostic and Interventional Radiology Research Center (ADIR), Breast Disease Research Center (BDRC), Imam Khomeini \\ Complex Hospital, Tehran, Iran \\ *Correspondence to: Masoumeh Gity (Email: Imamhospital@tums.ac.ir). \\ (Submitted:02 April 2021 - Revised version received: 25 April 2021 - Accepted: 12 May 2021 - Published online: 26 August 2021)
}

\begin{abstract}
Objectives The aim of this study was to assess whether is a reliable correlation between the cranial and gnathic angulations in the Iranian population.

Methods In a cross-sectional study, 140 patients of Tehran University of Medical Sciences hospitals (70 males and 70 females with an age range of 18-60 years) were selected. Sphenoclivus (cranial base) and gnathic angles were calculated for each case. Then, the data were analyzed using SPSS version 22

Results Statistical analysis showed a relationship between gnathic angle and female $(P<0.05)$, but no positive relationship was seen between sphenoclivus angle and gender. There was a significant relationship between sphenoclivus angle and age among men. No significant relationship was found between the gnathic and sphenoclivus angles.

Conclusion Sphenoclivus angle has the closest link with age in males. The gnathic angle has also a positive relationship with females. Our findings suggest an independent growth pattern between the sphenoclivus angle and the gnathic angle.

Keywords Anthropometry, sphenoclivus angle, cranial base angle, gnathic angle, cephalometric measurements
\end{abstract}

\section{Introduction}

Anthropology is a science that makes it possible to quantify the dimensions of the human body in different societies. ${ }^{1-3}$ Cephalometry as an important branch of anthropology being employed to calculate the dimensions of the head and face used in archeology, surgery, forensic medicine, medical engineering, and industry. ${ }^{4-6}$ In the clinical set, anthropometric studies of the craniofacial diameters can help in the diagnosis and predicting disorders. ${ }^{7}$ The measurement of each index in the craniofacial complex such as sphenoclivus and gnathic angulation is highly required to identify differences in the skull, predict the future skeletal jaw pattern of a child, and determine the best way to achieve brain tumors. ${ }^{8}$ Cephalometric measurements can be taken using either a digital tracing method or a traditional method. ${ }^{9}$ But computed tomography (CT) joined the tools of the anthropologist improving the volume of information. It allows us to study the anatomical characteristics of external and internal structures that can't be evaluated by the traditional morphometric instruments. ${ }^{5,10,1}$

However, so many studies have done to assess and compare the values of sphenoclivus angle and gnathic angle of each normal and abnormal skeletal group but very few studies are carried out to collect and group this information in Iran, and very rarely data exist to find the reliable relationship among the skeletal patterns of individuals. ${ }^{12}$

Thus in view of the fact, that the degree of its slope could also vary depending on the race or area in which the research was carried out. ${ }^{13}$ The present cephalometric study was conducted to find the difference in the values of sphenoclivus angle among Iranian adults and to explore the relationship between the sphenoclivus angle and gnathic angle.

\section{Materials and Methods}

This cross-sectional study was conducted from September 2018 to September 2019 in imaging centers affiliated with the Faculty of Medicine, Tehran University of Medical Sciences on 140 subjects (70 males and 70 females) aged between 18 to 60 years and the conscious consents were obtained. This study was approved by the ethics committee with the ID of IR.MEDICINE.TUMS.REC.1398.602. Subjects were selected randomly. 
Exclusion criteria were in the following:

- People with skull bone abnormalities (congenital or acquired).

- People with a history of trauma and skull fractures.

- People with a history of maxillofacial surgery, including cosmetic surgery.

- People of non-Iranian nationality.

The parameters were measured in the whole scans based on the following definitions:

Nasion: The middle point of the junction between the nasal bones with the frontal bone.

Basion: The midpoint of the anterior margin of the foramen magnum.

Prosthion: The lower edge of the maxillary alveolar process at the site of the anterior central teeth.

Pituitary point: The anterior edge of the sellaturcica.

Nasion-Basionline: It is a line connecting the nasion and basion.

Basion-Prosthion line: It is a line connecting the basion and prosthion.

Sphenoid plane: A plane that passes over the jugum of the sphenoid bone.

Basion-Pituitary line: It is a line connecting the basion and pituitary point.

Gnathic angle: It is an angle between the nasion-basion and basion-prosthion. Sphenoclivus angle (cranial base angle): It is an angle between the sphenoid plane and the basionpituitary point.

We first drew a line from the nasion to the basion and then a line from the basion to the prosthion. The angle between the two lines in terms of age and sex in a table and called it the gnathic angle (Fig. 1). In the next step, we measured the sphenoclivus angle, so that we consider a plane that passes over the jugum of the sphenoid to be the sphenoid plane. After that a line

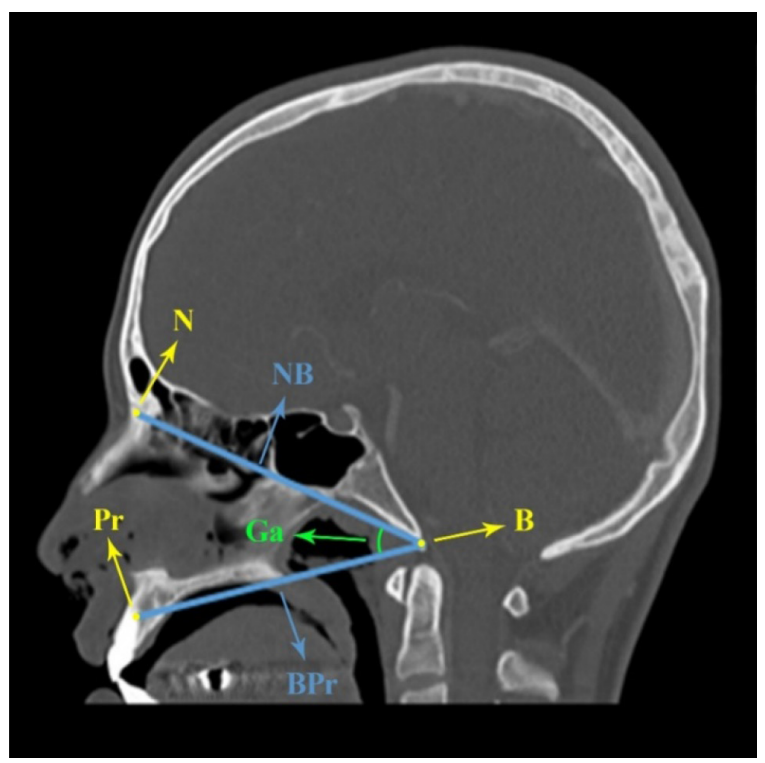

Fig. 1 Gnathic angle. This angle is between the Nasion-Basion line and the Nasion-Prosthion line. N: Nasion, B: Basion, Pr: Prosthion, NB: Nasion-Basion line, BPr: Basion-Prosthion line, Ga: Gnathic angle. from the basion to the pituitary point was drawn, now the angle between these two lines was named sphenoclivus angle (Fig. 2).

\section{Statistical Analysis}

The data were analyzed by SPSS software (Version 22). In this study, to describe quantitative variables, have been reported as mean \pm standard deviation (SD). Frequency and percentages were reported to describe qualitative variables. To compare the quantitative variables, the T-test, and to compare the qualitative variables, the chi-square test was used. Pearson's correlation coefficient test was used to obtain the correlations between quantitative variables. $P<0.05$ was considered statistically significant.

\section{Results}

The average angle of the sphenoclivus in women was found 110.200 degrees and in men with a difference of about two degrees seen 112.858. According to the chi-square test, there was no significant difference between the two genders in the sphenoclivus angle $(P=0.192)$. Chi-square test analysis also showed that the anthropometric measurement of the gnathic angle was significantly higher for females than that in males (0.023) (Table 1).

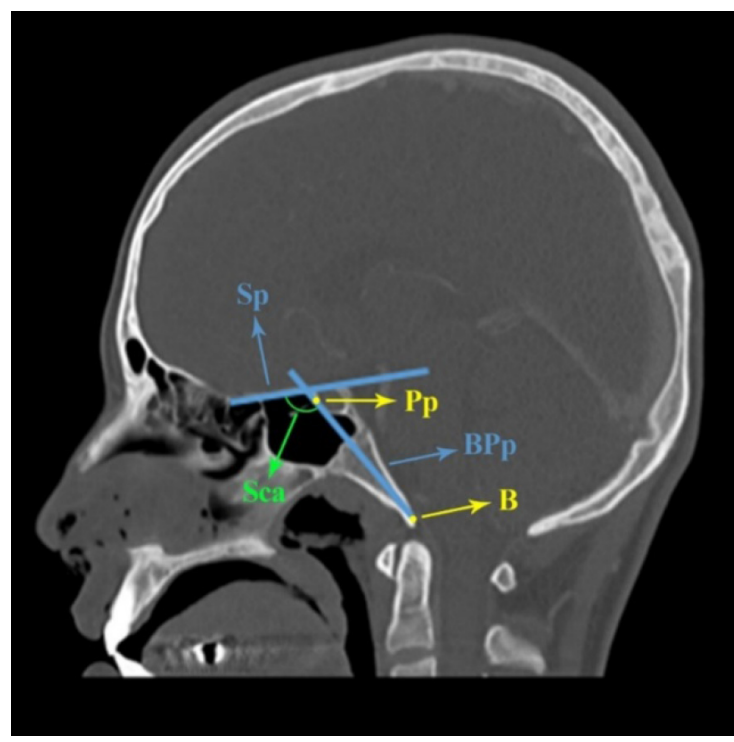

Fig. 2 Sphenoclivus angle. This angle is between the Sphenoid plane and the Basion-Pituitary point line. B: Basion, Pp: Pituitary point, Sp: Sphenoid plane, BPp: Basion-Pituitary point, Sca: Sphenoclivus angle.

Table 1. Comparing the anthropometric measurement of sphenoclivus angle and Gnathic angle between males and females in Iranian population

\begin{tabular}{|c|c|c|c|c|c|}
\hline & \multicolumn{4}{|c|}{ Gender } & \multirow[b]{3}{*}{$P$-value } \\
\hline & \multicolumn{2}{|c|}{ Male } & \multicolumn{2}{|c|}{ Female } & \\
\hline & Mean & SD & Mean & SD & \\
\hline $\begin{array}{l}\text { Sphenoclivus } \\
\text { angle }\end{array}$ & 112.858 & 7.637 & 110.200 & 15.7096 & 0.192 \\
\hline $\begin{array}{l}\text { Gnathic } \\
\text { angle }\end{array}$ & 36.915 & 3.5254 & 38.557 & 4.5550 & 0.023 \\
\hline
\end{tabular}


A significant correlation was observed between sphenoclivus angle and age in the male group. And, no positive relation was observed between gnathic angle and age in both genders (Table 2).

According to the statistical test performed in this study, there was no significant difference between the sphenoclivus angle and the gnathic angle in both genders with a correlation coefficient of 0.005 , it has predictive power (Table 3 ).

The volume of sphenoclivus angle increases in males with age. By using the following formula, through entering the age in this formula $(\mathrm{X})$, the size of the sphenoclivus angle can be predicted with a power of 0.25 (Fig. 3). $y=(0.59 \times x) \_27.08$

\section{Discussion}

The main goal of cephalometry is to elevate the relationships between the person's actual craniofacial morphology and

Table 2. Correlation between sphenoclivus angle and gnathic angle with age in Iranian population

\begin{tabular}{lcccc}
\hline & \multicolumn{2}{c}{ Male } & \multicolumn{2}{c}{ Female } \\
\cline { 2 - 5 } & $\begin{array}{c}\text { Correlation } \\
\text { coefficient }(\boldsymbol{r})\end{array}$ & P-value & $\begin{array}{c}\text { Correlation } \\
\text { coefficient }(\boldsymbol{r})\end{array}$ & P-value \\
\hline $\begin{array}{l}\text { Sphenoclivus } \\
\text { angle } \\
\begin{array}{l}\text { Gnathic } \\
\text { angle }\end{array}\end{array}$ & 0.251 & 0.026 & 0.053 & 0.681 \\
\hline
\end{tabular}

Table 3. Correlation between the gnathic and

sphenoclivus angle in Iranian population

\begin{tabular}{lcccc}
\hline & \multicolumn{3}{c}{ Male } & \multicolumn{2}{c}{ Female } \\
\cline { 2 - 5 } & $\begin{array}{c}\text { Correlation } \\
\text { coefficient }\end{array}$ & P-value & $\begin{array}{c}\text { Correlation } \\
\text { coefficient }\end{array}$ & P-value \\
\hline $\begin{array}{l}\text { Gnathic } \\
\text { angle }\end{array}$ & 0.005 & 0.963 & 0.058 & 0.702 \\
\hline
\end{tabular}

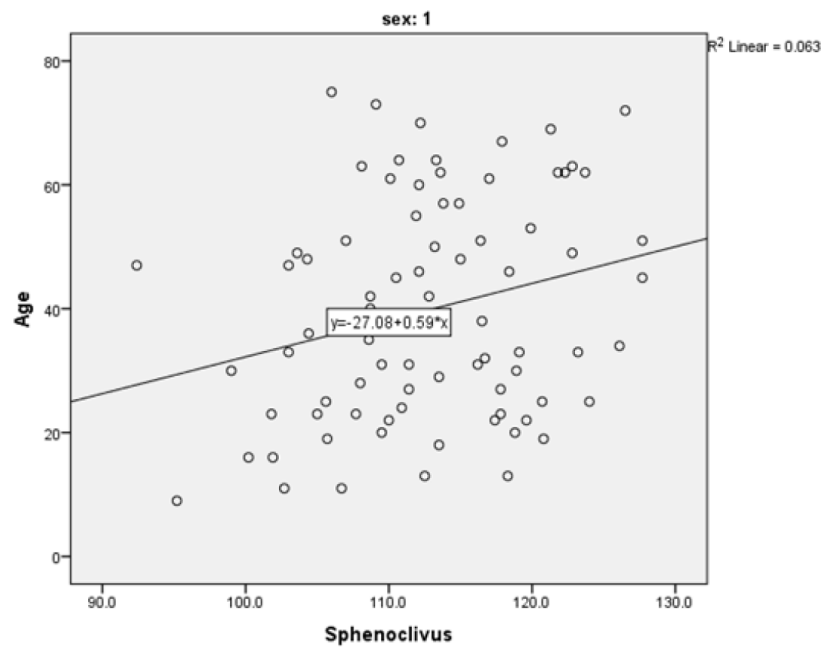

Fig. 3 Correlation between age and sphenoclivus angle among men predicted by regression models. those expected for his/her racial or ethnic group are discovered. ${ }^{9,14}$ Among all morphometric landmarks, the sphenoclivus angle serves as a reference structure to determine the skeletal type in the cephalometric analysis. ${ }^{15}$

In our study, the mean of the sphenoclivus angles was assessed $110.200^{\circ}$ in females and $112.858^{\circ}$ in males with no significant differences. Another study on Iranian showed the value of the cranial base angle in females is more than males. ${ }^{16}$ Although the presented data is in contrast with our findings in view of the fact that various Iranian ethnicities distribute all over the country, it is expectable to have different anthropometric features from city to city. Similar studies in India and Brazil also showed the wider sphenoclivus angle among females rather than males. ${ }^{17,18}$

Furthermore the differences between women and men, Table 4 shows the values of the cranial base angle can be found vary a lot in different places ${ }^{19-24}$ although, several authors declare that some anomalies such as herniation of the cerebellum, Chiari malformations, malocclusion and craniocervical junction abnormality associated with the changes of this angle. Royo-Salvador affirmed that there is platybasia when the cranial base angle is more than $140^{\circ 25}$ but some authors declared that the cranial base angle surpasses $140^{\circ}$ and do not agree on the limit value for considering a skull platybasia. ${ }^{17}$ In agreement with these reports, a study in Finland showed the sphenoclivus in both normal and otosclerosis patient groups was the same and no significant changes in degree were mentioned among Finnish people. ${ }^{26}$ More studies stated that the bigger sphenoclivus angles exist among the normal group in comparison with the Chiari patients group in turkey ${ }^{23}$ versus Brazilian revealed the more value sphenoclivus angle among the normal group. ${ }^{27}$ Although there was a slight difference between the mean values for the normal and patients groups but no significant differences between the two groups were reported. Moreover some anthropologists mentioned a positive correlation between the slope of sphenoclivus angle and skin color so that this angle was calculated more than $125^{\circ}$ and wider among the nonwhite population in comparison to that in white one. ${ }^{17}$ Therefore, the degree of the slope could be vary depending on the ethnicity, race, or area in which the research was carried out. ${ }^{13}$ So it is necessary to know in detail the anatomical structures to have a database bank for the comparison between normal and patient's samples although our project only focused on the sphenoclivus angle in the normal population.

Regarding the relation between age and the value of the sphenoclivus angle, we found a significant correlation between age and this angle in males so that the older men, the wider sphenoclivus angle value. In contrast with our results, some anthropologists declared that there was no relation between age and the value angle. ${ }^{17,18}$ Moreover, the consensus of different authors proved that the sphenoclivus angle has a considerable influence upon the mandibular and maxilla position, thus it determines the skeletal jaw pattern of an individual. Although other researchers have obtained conflicting evidence, that there is no connection between the cranial base angle and the static position of the jaw. ${ }^{21,28}$

In spite of cranial base angle malformation, gnathic angle changes are presented as an index showing the presence of impairment in the sub nasal area of individuals. In comparison to the sphenoclivus angle, our results found no significant correlation between gnathic angle and age. Although, a positive relationship between gnathic angle and gender was seen. 
Table 4. Comparison of measured Sphenoclivus angle in different studies

\begin{tabular}{lcccccccccccc}
\hline & \multicolumn{10}{c}{ Place of study } \\
\cline { 2 - 6 } & $\begin{array}{c}\text { Tehran, } \\
\text { Iran }\end{array}$ & $\begin{array}{c}\text { Isfahan, } \\
\text { Iran }\end{array}$ & Brazil & India & Turkey & Kenya & Spain & Brazil & USA & Japan & Romania & USA \\
\hline $\begin{array}{l}\text { Sample } \\
\text { number }\end{array}$ & 140 & 100 & 160 & 255 & 43 & 100 & 292 & 33 & 10 & 46 & 50 & 96 \\
$\begin{array}{l}\text { Reference } \\
\text { number }\end{array}$ & $\begin{array}{c}\text { Present } \\
\text { study }\end{array}$ & 15 & 16 & 17 & 22 & 23 & 24 & 26 & 18 & 19 & 20 & 21 \\
Female & 110.2 & 131.72 & 115.56 & 131.42 & - & - & - & - & - & - & - & - \\
Male & 112.85 & 128.65 & 115.28 & 129.7 & - & - & - & - & - & - & - & - \\
Mean & - & - & - & - & 121 & $103-143$ & $115-140$ & $107-132$ & $107-124$ & 133.96 & 131.4 & 129.80 \\
\hline
\end{tabular}

Remarkably, no reliable correlation was reported between sphenoclivus and gnathic angles. Our findings indicate the independent growth pattern between two important indexes of the craniofacial complex and vastly express the necessity for collecting the morphometric information not only in the different populations but also in different genders separately.

\section{Conclusion}

In conclusion, with regard to this fact that many more studies are still needed on the measurement and analysis of craniofacial indexes. Our results indicate that the sphenoclivus and gnathic angles have no significant relation with each other in the Iranian population. A significant relationship exists between the gnathic angle and gender in females. But, only sphenoclivus angle has a positive relationship with age in males.

\section{Acknowledgment}

The authors would like to appreciate the effort of all those who helped to enrich this project. Special gratitude also goes to all the 140 patients of Tehran University of Medical Sciences hospitals selected in this study.

\section{Conflicts of Interest}

None declared.

\section{References}

1. Mohammed I, Mokhtari T, Ijaz S, Ngaski AA, Milanifard M, Hassanzadeh $G$. Anthropometric study of nasal index in Hausa ethnic population of northwestern Nigeria. Journal of Contemporary Medical Sciences. 2018;4(1).

2. Zolbin M, Hassanzadeh G, Mokhtari T, Arabkheradmand A, Hassanzadeh S. Anthropometric studies of nasal parameters of Qazvin Residents, Iran. MOJ Anat Physiol. 2015;1(1):00002.

3. Ebrahimi B, Madadi S, Noori L, Navid S, Darvishi M, Alizamir T. The stature estimation from students' forearm and hand length in Hamadan University of Medical Sciences, Iran. Journal of Contemporary Medical Sciences. 2020;6(5).

4. Navaei F, Ghaffari N, Mojaverrostami S, Dodongeh M, Nemati M, Hassanzadeh G. Stature estimation from facial measurements in medical students of Tehran university of Medical Sciences: an Iranian population. lraq Medical Journal. 2018;2(3):68-71.

5. Dodangheh M, Mokhtari T, Mojaverrostami S, Nemati M, Zarbakhsh S, Arabkheradmand A, et al. Anthropometric Study of the Facial Index in the Population of Medical Students in Tehran University of Medical Sciences. GMJ Medicine. 2018;2(1):51-7.

6. Ebrahimi B, Nemati M, Dodangeh M, Hassanzadeh G. Stature estimation from cranial indices in students of Tehran University of Medical Sciences. Scientific Journal of Forensic Medicine. 2021;26(4):0-

7. Hassanzadeh S, Alemohammad ZB, Mokhtari T, Arabalidoosti F, Rezaei F. Correlation between craniofacial parameters and obstructive sleep apnea syndrome in Iranian population. Iraq Medical Journal. 2019;3(2).

8. Olszewski R, Frison L, Schoenarts N, Khonsari R, Odri G, Zech F, et al. Reproducibility of three-dimensional posterior cranial base angles using low-dose computed tomography. Clinical oral investigations. 2017;21(8):2407-14.

9. Darkwah WK, Kadri A, Adormaa BB, Aidoo G. Cephalometric study of the relationship between facial morphology and ethnicity. Translational Research in Anatomy. 2018;12:20-4.

10. Mantini S, Ripani M. Modern morphometry: new perspectives in physical anthropology. New biotechnology. 2009;25(5):325-30.

11. Mohamadi Y, Mousavi M, Pakzad R, Hassanzadeh G. Anthropometric parameters for access to sella turcica through the nostril. Journal of Craniofacial Surgery. 2016;27(6):e573-e5.
12. Kaestle FA, Horsburgh KA. Ancient DNA in anthropology: methods, applications, and ethics. American Journal of Physical Anthropology: The Official Publication of the American Association of Physical Anthropologists. 2002;119(S35):92-130

13. Camcı H, Salmanpour F. Cephalometric Evaluation of Anterior Cranial Base Slope in Patients with Skeletal Class I Malocclusion with Low or High SNA and SNB Angles. Turkish Journal of Orthodontics. 2020; 33(3): 171.

14. Ghaffari N, Ebrahimi B, Nazmara Z, Nemati M, Dodangeh M, Alizamir T. Assessment of Gender Dimorphism Using Cephalometry in Iranian Population. Iraq Medical Journal. 2020;4(4).

15. Cossio L, López J, Rueda ZV, Botero-Mariaca P. Morphological configuration of the cranial base among children aged 8 to 12 years. BMC Research notes. 2016;9(1):309.

16. Monirifard M, Sadeghian S, Afshari Z, Rafiei E, Sichani AV. Relationship between cephalometric cranial base and anterior-posterior features in an Iranian population. Dental Research Journal. 2020;17(1):60.

17. Netto DS, Nascimento SRR, Ruiz CR. Metric analysis of basal sphenoid angle in adult human skulls. Einstein (São Paulo). 2014;12(3):314-7.

18. Gupta PP, Dhok AM, Shaikh ST, Patil AS, Gupta D, Jagdhane NN. Computed tomography evaluation of craniovertebral junction in asymptomatic central rural Indian population. Journal of Neurosciences in Rural Practice. 2020;11(3):442

19. Lieberman DE, Ross CF, Ravosa MJ. The primate cranial base: ontogeny, function, and integration. American Journal of Physical Anthropology: The Official Publication of the American Association of Physical Anthropologists. 2000;113(\$31):117-69.

20. Kasai K, Moro T, Kanazawa E, Iwasawa T. Relationship between cranial base and maxillofacial morphology. The European Journal of Orthodontics. 1995;17(5):403-10.

21. Panainte I, Suciu V, Mártha K-I. Correlation between cranial base morphology and various types of skeletal anomalies. Journal of Interdisciplinary Medicine. 2017;2(s1):57-61.

22. Steinberg B, Fraser B. The cranial base in obstructive sleep apnea. Journal of oral and maxillofacial surgery. 1995;53(10):1150-4.

23. Karagöz F, Izgi N, Sencer SK. Morphometric measurements of the cranium in patients with Chiari type I malformation and comparison with the normal population. Acta neurochirurgica. 2002;144(2):165-71. 
24. Adam A. Skull radiograph measurements of normals and patients with basilar impression; use of Landzert's angle. Surgical and Radiologic Anatomy. 1987;9(3):225-9.

25. Royo-Salvador M. Platybasia, basilar groove, odontoid process and kinking of the brainstem: a common etiology with idiopathic syringomyelia, scoliosis and Chiari malformations. Revista de neurologia. 1996;24(134):1241-50.
26. Vuorinen $\mathrm{P}$, Meurman $\mathrm{OH}$. The basal angle in the clinical diagnosis of otosclerosis. Acta oto-laryngologica. 1962;54(1-6):176-80.

27. Botelho RV, Ferreira EDZ. Angular craniometry in craniocervical junction malformation. Neurosurgical review. 2013:36(4):603-10.

28. Bhattacharya A, Bhatia A, Patel D, Mehta N, Parekh H, Trivedi R. Evaluation of relationship between cranial base angle and maxillofacial morphology in Indian population: a cephalometric study. Journal of orthodontic science. 2014;3(3):74.

This work is licensed under a Creative Commons Attribution-NonCommercial 3.0 Unported License which allows users to read, copy, distribute and make derivative works for non-commercial purposes from the material, as long as the author of the original work is cited properly. 